\title{
AN UNDERSTANDING OF SOME INTERPRETATIONS OF THE QUR'AN BY TEXTUAL AND CONTEXTUAL APPROACHES
}

\author{
Ahmad Syukri Saleh \\ Sulthan Thaha Saifuddin State Islamic University Jambi \\ ahmadsyukrisaleh65@gmail.com
}

\begin{abstract}
Several efforts have been recently made by Muslim scholars in understanding the true meaning of the Qur'an. This is proven by more and more publications concerning the interpretation of the Qur'an come into existence. Moreover, the development of commentary of the Qur'an has produced a variety of approaches and methods in perceiving the message of the Qur'an. This positive trend, of course, should be strongly appreciated. Despite having the bulk of treatises on the commentary of the Qur'an, it does not make much easier for Muslim in general to understand its meaning. There are some Muslims who perceive the verses of the Qur'an only by textual approach regardless of the real meaning and purpose represented by the verse itself. In other words, understanding the verses of the Qur'an without considering its context. Therefore, it would be necessary to conduct an intensive research regarding some interpretations of the Qur'an which seem apparently simple but are not appropriate. A mistake in interpreting the verses of the Qur'an might lead to misunderstanding the message under consideration. This article aims at elucidating some misinterpretations of the verses of the Qur'an that should be placed within their proper contexts. This is conducted through library research by exploring some popular references on the commentary of the Qur'an.
\end{abstract}

Keywords: Textual and Contextual Approaches

\section{Introduction}

It has been a reality that several efforts on studying and understanding the Qur'an occurred in the course of Muslim history. The efforts would continue until the end of this world, as long as Muslim keeps using their rational thought to apprehend a true meaning of the Qur'an, particularly in encountering some crucial issues in the recent years. The process of understanding the Qur'an is strongly related to text and context to obtain a proper understanding. Although, up to now, it is still witnessed those who perceive the Qur'an textually, there are some others who understand it contextually. For example, what for a word, a phrase or a sentence expressed in the Qur'an is used, in what condition, and in what sense. At a glance, these approaches seem complicated, since one should observe every angle of the verses of the Qur'an. However, if it is done, there would be found a comprehensive understanding of the message of the Qur'an.

With regard to how important for the commentators of the Qur'an paying an attention on the context, besides its text, Shihab reminds that there are several factors which lead someone made a mistake in interpreting the Qur'an, among others namely: "(a) his/ her own vested interest; (b) applying inappropriate methods; (c) shortcoming on mastering language; (d) inadequate horizon on the subject under consideration; (e) neglecting its context which related to either historical background of the text, correlation between the text or social condition of the community); and (f) paying no attention to those who become subject and object of the verses" $(1992,79)$.

A mistake often happens when an interpretation of a word in the Qur'an generalized into one meaning only. In fact, if it is closely scrutinized, a word which is according to its derivation might be similar but, sometimes, it probably contains a 
different meaning when its context is taken into consideration. For instance, the word fitna which several times expressed in the chapter al-Anfâl and al-Tawbah. Lexically speaking, this word translated as an exam. Nevertheless, if it is traced in these two chapters of the Qur'an, fitna refers to a different meaning. In al-Anfâl/8: 25 mentioned that: "And fear tumult or oppression, which affecteth not in particular (only) those of you who do wrong" ("Ali, 2008, 216). Then, in the verse 28 mentioned that: "And know ye that your possessions and your progeny are but a trial ..." ('Ali, 2008, 216). While in alTawbah/9: 48, it is mentioned that: "Indeed they had plotted sedition before, and upset matters for thee, ..." ('Ali, 2008, 233). If one word of the Qur'an in several verses and chapters might have different interpretations, more and more interpretations which involve some words in a verse or a chapter, of course, inevitably have also significantly different meaning.

Another mistake also happens when understanding the meaning of the Qur'an related to what so far deemed true and has popularly rooted in Indonesian Muslim societies. For example, the meaning of the word fitna in Indonesian language refers to disseminating information containing hoax and having discredited one's behavior or an accusation without any basis, as implemented when perceiving chapter al-Baqarah/2: 191 and 217 saying that: "al-fitna ashadd min al-qatl and al-fitna akbar min al-qatl which each of them translated as "fitna crueler than murder" (Rifhan, 2009, 52,59). Is this a true meaning of both verses of the Qur'an?

According to Shihab, the word fitna in those verses mean "persecution, physical torture, seizing property, family isolation, intimidation and expelling people from their homeland executed by pagan Mecca. All these are crueler than murder. This kind of meaning seems relevant to its context, including its historical background" (2006, I, 421, 462). Marmaduke Pickthall, in his book The Meaning of the Glorious Koran, I think, offers a more accurate translation on this verse by saying "for persecution is worse than slaughter" and "persecution is worse than killing" (n.d., 50, 52). In a quite similar expression, "Ali would consistently interpret the verse under consideration that "for tumult and oppression are worse than slaughter" $(2008,51,56)$.

In line with this, another mistake occurs when understanding the Qur'an which is irrelevant with its represented word. For instance, chapter al-Ra'd/13: 11 states that: "Verily never will God change the condition of a people until they change it themselves (with their own souls)" ("Ali, 2008, 294). This verse frankly mentions a change in collective way, indicated by the word qaum but often understood as individual change. A quite same expression also found in the chapter al-Anfâl/8: 53 states that: "Because God will never change the grace which $\mathrm{He}$ hath bestowed on a people until they change what is in their (own) souls: and verily God is He Who heareth and knoweth (all things)" ('Ali, 2008, 220). If it is closely observed, al-Ra'd/13: 11 actually talks about change in global context, either it brings benefit or harm for a community, whereas alAnfal/8: 53 concentrates on a specific change, particularly with regard to God bounty to the community (al-Marâghî, n.d., 78; Shihab, 2006, VI: 568).

Having observed on the importance of understanding the verses of the Qur'an comprehensively, both textual and contextual meanings, this article should have a chance to pursue the discussion to make the reader finds an accurate description on the meaning of Qur'anic verses. Several questions might eventually arise in our mind, such as should the verse understood textually or contextually? How do we understand the passage of the Qur'an comprehensively? Is this approach relevant to the demand of contemporary Muslim community? This article aims at answering above questions and elucidating some misinterpretations of the verses of the Qur'an that should be placed within their proper contexts. 


\section{Literature Review}

Having surveyed several books concerning this topic, I do not find a specific discussion on the importance of understanding the verse of the Qur'an through textual and contextual approaches. Although these two approaches might separately be implemented to produce a meaning, the use of similar word in the Qur'an cannot be generalized into one meaning only, it however should be placed within its context. Since the context may also contribute in clarifying the meaning. With regard to this assertion, Fazlur Rahman aptly maintains that, "[t]o insist on a literal (textual) implementation of the rules of the Qur'an, shutting one's eyes to the social change that has occurred and that is so palpably occurring before our eyes, is tantamount to deliberately defeating its moral-social purposes and objectives" (1982,19). Mahmûd (1990) quotes al-Mahdawî's opinion saying that the use of definite article (alif lam) in several words of the Qur'an may influence the meaning which they produced. Al-Zarqani (1998) also shows how the Prophet interpreted some verses of the Qur'an which refer to other verses in order to obtain a clear meaning of the Qur'an. In addition, Ibn Taîmiyyah (1971) and Banna (2004) insist on the importance of historical background (asbâb al-nuzhl) of the verses in clarifying the meaning of the Qur'an under investigation.

\section{Methods}

This article discusses the importance of understanding the Qur'an through both textual and contextual approaches. This is conducted through library research by exploring some popular references on the interpretation of the Qur'an. Data are collected through several books which related to the commentary of the Qur'an and its methodology. Discussion focuses on several verses which are understood literally, while its contexts are neglected and vice versa. Each meaning of the verses under consideration would be traced according to its usage in order to find a more accurate comprehension on the message of the Qur'an.

\section{The Definition of Textual and Contextual}

Before discussing how do we understand the Qur'an both textually and contextually, I think, it is worthwhile to present firstly the meaning of text and context itself. Lexically speaking, the word "text" has several meanings, among others: "1) [t]he original words of something written or printed and; 2) A passage from the Scriptures or another authoritative source used as the basis for a discourse or an argument" (Jost, 1993, 1403). Meanwhile, the word "textual" means "relating to the way of a work of literature is written" (Sinclair, 1993, 1510). In brief, I would say that "textual" is connected with an expression of a wording in a book, article, including text in Scriptural books.

Then, the word "context" also has some meanings, namely:"1) [t]he part of a text or statement that surrounds a particular word or passage and determines its meaning and: 2 ) the circumstances in which an event occurs; a setting". While the word "contextual" constitutes an adjective form of context which means "involving, or depending on a context" (Jost, 1993, 301). Therefore, I would say that, contextual is a situation which relates to the context in order to clarify the meaning of a word and to describe the background of an event under discussion. After all, methodologically speaking, it is understood that textual constitutes a restricted meaning on the basis of its wording. While contextual might produce several meanings which are different with their texts after having considered situations surround them, but are still on the limitations of the words represented. Now, we shall continue to discuss how do we understand the Qur'an by using its textual approach. 


\section{Understanding the Qur'an through a Textual Approach}

To understand the Qur'an textually means understanding which is done on the ground of literal meaning of the word. This is an easy way to comprehend because the meaning is so closely related to the word. It usually uses the words that are synonymous. These are found in several editions of translation of the Qur'an, particularly word-for-word translation. When a verse is textually understood, the meaning produced is not far from the original text, even it constrains to the text. This means that if a verse mentions a sermon towards the believers, it spontaneously refers to the believers only. Having observed al-Baqarah/2: 183 saying that "O ye who believe! Fasting is prescribed to you as it was prescribed to those before you, that ye may (learn) self-restraint" ("Ali, 2008, 50 ), one may understand that the obligation to perform fasting in the month of Ramadan is only for the believers since the verse textually says so. A quite clear illustration might be found in al-Baqarah/2: 21 saying that " $\mathrm{O}$ ye people! Adore your Guardian- Lord, Who Created you and those who came before you, that ye may have the chance to learn righteousness" ("Ali, 2008, 25). This verse textually indicates the call for mankind to worship God Who created them and those who came before them. The purpose of this worship is to make them righteous people. Another illustration might be noticed in alMâ'idah/5: 38 states that "[a]s to the thieft, male or female, cut off his or her hands: a punishment by way of example, from God, for their crime: and God is Exalted in power" ('Ali, 2008, 139). This verse indicates a textual meaning that if a male or female conducts a thieft crime, the punishment for such a deed by cutting off their hands. Through this approach, one does not necessarily need to trace its historical background since the wording of the verse demonstrates a clear meaning.

An understanding the Qur'an in a textual approach would be called as an embrio of the commentary of the Qur'an, since at the beginning of Islam, the quantity of $t \mathrm{~h} \mathrm{e}$ commentary of the $\mathrm{Qur}$ ' a n does not as many as the later era, particularly after the development of some disciplines, including the Science of the Qur'an ('Ulûm al-Qur'ân). As acknowledged, in the era of the Prophet, the understanding of the Qur'an was so simple by referring to a similar or closely related word in another chapter. This was practiced by the Prophet when interpreting al-An'âm/6: 82 with Luqmân/31: 13. At that time, some companions confused to comprehend the meaning of "zhulm" in which they will be in security and on the right guidance if they do not mix with their beliefs and wrong deed. They wonder how come they would release from these two situations. Then the Prophet explained that "wrong deed" intended by the verse was related to joining other god beside Allah as mentioned in Luqmân/31:13.

Some scholars have presented a plenty of verses which are interpreted by other verses, either in the same chapter or not. For instance, the word "kalimât" in alBaqarah/2: 37 is textually interpreted by al-A'râf/7: 23 . God says in al-Baqarah/2: 37 that " $[t]$ hen learnt Adam from his Lord words of inspiration, and his Lord turned towards him; for $\mathrm{He}$ is Oft-returning, Most Merciful" ("Ali, 2008, 28). Words of inspiration in the verse is interpreted by al- A'râf/7: 23, where God teaches both Adam and his wife the following words "... Our Lord! We have wronged our own souls: if Thou forgive us not and bestow not upon us Thy Mercy, we shall certainly be lost" ("Ali, 2008, 184; alZarqânî, 1998, 17). Both verses constitute a story of Adam and his wife, Eva, when they did a big mistake transgressing Allah's order and what should be done to release from it. This kind of interpretation is well-known called tafsîr bi al-ma'tsûr. Its interpretation, so far, however is only effective to the verses of the Qu'r'an concerning law and sociological matters, while for theological one has not been sufficient yet, particularly to what is so called mutsyâbihât. Since, if it is interpreted textually, it may affect to the quality of man 
faith as Muslim. For example, when interpreting the phrase "yad Allâh fauq aydihim" (the Hand of God is over their hands) as mentioned in al-Fath/48: 10. Having perceived this textually, it would make an understanding that one bravely equalizes God Hand with the hands of His creatures. Henceforth, this kind of interpretation could not be absolutely followed. Even, the Prophet himself was ever reported to interpret the word quwwah in alAnfâl/8: 60, which textually meant "power" but it contextually was changed to an " arrow" (al-ramyu), namely the ability to defeat the enemy by using an arrow (al-Zarqânî, 1998, 18). The Prophet also contextually interpreted the word al-maghdhûb and al-Dhâllin mentioned in al-Fâtihah/1: 7 with "the Jews" and "the Christians" (Ibn Kathîr, n.d., I, 29). In short, one may conclude that there are some verses which have suitable interpretation by using textual approach, but there are some others which should be perceived through contextual one. An interesting discussion that should be noticed by the reader on this field.

\section{Understanding the Qur'an through a Contextual Approach}

As acknowledged earlier, the verses of the Qur'an sometimes cannot be understood properly by only using a textual approach, so it is crucial to explain when and how one can implement a contextual approach. Understanding the Qur'an contextually is implemented when there is no satisfied interpretation produced by textual approach. This approach is done by exploring other meanings which might be included and are relevant to the word under consideration. Such understandings could directly refer to several important aspects which covering the existence of word of the Qur'an, either that connected with linguistics by tracing similar vocabulary and a variety of meanings produced or restricting the meaning and explanation regarding situation, event and its background. Henceforth, it would be worthwhile when earlier Muslim scholars introduced several disciplines which might help the reader in understanding the Qur'an comprehensively such as the science of makkîyah and madanîyah, asbâb al-nuzûl, nâsikh and mansûkh and so forth. In this article, I would only focus the discussion on understanding the Qur'an based upon linguistics and its historical background.

Understanding the Qur'an based on linguistics approach could be seen when one observes al-Mâ'idah/5: 38 stating that "As to the thief, male or female, cut off his or her hands: a punishment by way of example, from God, for their crime: and God is Exalted in power ('Ali, 2008, 139). According to al-Mahdawî, as quoted by Muștafâ Maḥmûd, the word al-sâriq (the male thief) and al-sâriqah (the female thief) are expressed by using alif and lam ma'rifah (definite article) cannot be perceived as thief in general. The use of definite article in front of the word sâriq and sâriqah indicates a restricted meaning for those thieves who conducted the crime more than once, I would say professional. While for those who conducted it for the first time due to a necessity or forced by other cannot be punished by cutting off their hands. In line with this, the word al-zâniyah and al-zânî, as mentioned in al-Nûr/24: 2 saying that "[t]he woman and the man guilty of adultery or fornication, flog each of them with a hundred stripes ..." ('Ali, 2008, 421), also directed to the woman and man who conducted adultery more than once. Since both al-zânîyah and al-zânî expressed by using definite article, it cannot be equalized with those who conducted adultery for the first time due to their mistakes and having persuaded by satan. Therefore, this verse is more appropriate implemented to the man and the woman who involved in prostitution business (Maḥmûd, 1990, 74-75).

Furthermore, understanding the Qur'an based upon its historical background (asbâb al-nuz $\hat{u} l$ ) could be observed from al-Mâ'idah/5: 39. It is narrated that in the era of the Prophet, there was a woman from Banî Makhzûm well-known as Murra binti Sufyân who conducted a crime (theft). Then this incident was reported by bringing the woman to 
the Prophet. They said: "This is a woman who stole our property, while her tribe tries to offer a compensation." The Prophet then commands to cut off her hand, but her tribe attempts to save the woman by offering five hundred dinars as compensation. However, the Prophet insists with his command to cut off the woman's hand. After having her hand being cut off, the woman asked the Prophet whether her repentance was still accepted. The Prophet replied: "Yes, you are clean from your sin as you are newborn by your mother" Then God sent down this verse (Ibn Kathîr, n.d., II, 57) stating that "But if the thief repents after his crime, and amends his conduct, God turneth to him in forgiveness; for God is Oft-forgiving, Most Merciful" ("Ali, 2008, 139). From above illustration, it is clear that understanding the Qur'an through contextual approach makes the reader easily to comprehend the reason behind the verse which sent down to the Prophet.

Meanwhile, there is an opinion asserting that cutting off the hand in such verse constitutes maximum limit, so when it is found the situation which makes the sanction more lighten, the judge may give other minimal punishment instead of cutting hand. Even though it is not explicitly stated in the verse, this understanding could be accepted if there is a reason which makes the punishment reduced to minimal limit as practiced by 'Umar bin al-Khatțâb due to necessity and hardship. Likewise, 'Umar did not punish some workers who stole a camel since their employer did not give an appropriate reward to them. Conversely, Umar put a sanction to the employer namely Ibn Hațíb bin Abî Balta'ah to compensate by burdening an obligation to pay a double price to the owner of camel (Shihab, 2006, III. 94-95). According to Fazlur Rahman, Umar was very famous for his decision when he "suspended the Hadd punishment for the theft during a period of acute scarcity of food" $(1984,182)$.

Several illustrations above proved how urgent to trace and identify the context behind the text. If it is ignored by someone who wants to understand the Qur'an, he would fail to catch the real meaning of the verse. As for historical background, Ibn Taîmiyyah (d. 728/1328) put his serious attention by stating that "knowing the historical background of the verse might be helpful in understanding the Qur'anic verse, since knowledge about the cause would produce knowledge about the motive" $(1971,47)$.

It is noteworthy that comprehending the Qur'anic verses through contextual approach is indeed necessary, but when one wants to interpret the verse on the basis of its historical background, he should at first carefully confirm the quality and the rationale of narrative tradition under investigaton. Let us pay attention to the following verse (alAhzâb/33: 53) saying that: “... Nor is it right for you that ye should annoy God's Messenger, or that ye should marry his widows after him at any time. Truly such a thing is in God's sight an enormity" ('Ali, 2008, 516). When interpreting this verse, alSuddî tells that Țalhah bin "Abd Allâh said that: "Does Muhammad forbid us to marry daughters of our uncle, while he freely marries our former wives? If something happens with him (the Prophet has passed away), we would like to marry his wives". Then, this verse sends down. To respond this, Ibn Sa'ad, on the basis of a narration from Abû Bakr bin Muhammad bin 'Amr bin Hazm, states that this verse related to Talhah's statement who wants to marry 'Â' ishah when the Prophet was die. This statement is difficult to be justified since Talhah is one of earlier companions converted to Islam and has been guaranteed by the Prophet to enter the paradise. Such narrator's statement is only appropriate uttered by the pagan Badui (Banna, 2004: 89). Having observed this, one should first carefully examine the narration before using it as the basis of his interpretation in understanding the verse of the Qur'an contextually.

\section{Conclusion}

To sum up this article, I would say that understanding the interpretation of the 
Qur'an should be a prime concern for the Muslim scholars nowadays, particularly in solving several contemporary problems encountered by the community. In doing so, they should be able to select an appropriate approach to interpret the Qur'an. As for interpreting the verses of the Qur'an, there are two approaches which can be undertaken, either textually or contextually. There are some verses which can be understood through a textual approach, while others need to be comprehended by way of contextual one. Both approaches may contain plus and minus result. Henceforth, before interpreting the Qur'an, one should survey the related words which are suitable to find the right answer. At the same time, he also should explore additional explanation concerning the usage of the word or historical background for the verses under investigation. The combination of these two approaches, in my opinion, might be the best option in order to understand the Qur'an comprehensively.

\section{References}

'Ali, 'Abdullah Yusuf. (2008). The Holy Qur'an: Original Arabic Text with English Translation \& Selected Commentaries. Kuala Lumpur: Saba Islamic Media.

Banna, Gamal. (2004). Evolusi Tafsir: Dari Jaman Klasik hingga Jaman Modern (Tafsîr al-Qur'ân bayn al-Qudamâ' wal Muhaddithîn). Indonesian Translation by Novriantoni Kahar. Jakarta: Qisthi Press.

Ibn Kathîr, Abî al-Fidâ' Ismâ'îl. (n.d.) Tafsîr al-Qur'ân al-'Azhîm. Vol. I and II Egypt: Dâr al-Kutub al-Mișriyah.

Ibn Taîmiyyah, Taqi' al-Dîn Aḥmad bin 'Abd al-Ḥalim. (1971). Muqaddimah fí Ushûl alTafsîr. Ed. Adnan Zurzur. Kuwait: Dar al-Qur'an al-Karim.

Jost, David A. et al. (1993). The American Heriatge College Dictionary. Boston and New York: Houghton Mifflin Company.

Maḥmûd, Muștafâ. (1990). Sekelumit Rahasia al-Quran (Min Asrâr al-Qur'ân). Indonesian Translation by Muhdhar Husain Syahab. Singapura: Pustaka Nasional.

Al-Marâghî, Aḥmad Mușțafâ al-Marâghî. (n.d.) Tafsîr al-Marâghî. Vol. V. Beirut: Dâr alFikr.

Pickthall, Marmaduke. (n.d.). The Meaning of the Glorious Koran. New York: Dorset Press.

Rahman, Fazlur. (1982). Islam \& Modernity: Transformation of an Intellectual Tradition. Chicago: The University of Chicago Press.

------. (1984). Islamic Methodology in History. Islamabad: Islamic Research Institute.

Rifhan, Arif et al. (Eds.). (2009). Al-Qur'an Tiga Bahasa. Depok: Penerbit Huda.

Shihab, M. Quraish. (1992). Membumikan Al-Quran. Bandung: Mizan.

-----. 2006). Tafsir al-Mishbâh. Vol. I, III and VI. Ciputat. Lentera Hati.

Sinclair, John et al. (1993). Collins Cobuild English Language Dictionary. London: HarperCollins Publishers.

Zarqânî, Muhammad 'Abd al-'Azhîm. (1998). Manâhil al-Irfân fî 'Ulûm al- Qur'ân. Vol. II. ed. Badî’ al-Sayyîd al-Laḥhâm. Dâr al-Qutaybah. 